\title{
HIGH SCHOOL STUDENTS' ATTITUDES TOWARDS MATHEMATICS LESSONS USING THE PQ4R STRATEGY AND PROBLEM POSING MATHEMATICAL PROBLEMS
}

\author{
Taufiqulloh Dahlan ${ }^{1}$, Darhim ${ }^{2}$, Dadang Juandi ${ }^{3}$, Nia Gardenia ${ }^{4}$, Thesa Kandaga ${ }^{5}$ \\ ${ }^{1}$ Universitas Pendidikan Indonesia, Jl. Dr. Setiabudi No.229, Bandung, Indonesia, \\ taufiqulloh@upi.edu \\ ${ }^{2}$ Universitas Pendidikan Indonesia, Jl. Dr. Setiabudi No.229, Bandung, Indonesia \\ darhim0355@gmail.com \\ ${ }^{3}$ Universitas Pendidikan Indonesia, Jl. Dr. Setiabudi No.229, Bandung, Indonesia \\ dadang.juandi@upi.edu \\ ${ }^{4}$ Universitas Indraprasta PGRI Jakarta, Jl. Raya Tengah No. 80, Jakarta, Indonesia, \\ niagardenia140813@gmail.com \\ ${ }^{5}$ Universitas Pasundan, Jl. Tamansari No.6-8, Bandung, Indonesia, \\ thesakandaga@unpas.ac.id
}

\begin{abstract}
This study aimed to examine students 'attitudes or perceptions of mathematics learning, attitudes towards the Application of PQ4R (Preview, Question, Read, Reflection, Recite, Review) Learning Strategies, and problem posing mathematical problems. Data were analyzed using a qualitative descriptive data analysis, and quantitative analysis was carried out using the Likert scale. The population in this study were Year 11 students in the city of Bandung, and the sample was one of Year 11 Social classroom as the experimental class, selected by purposive sampling. The sample was given treatment using PQ4R learning. The results showed that students taking PQ4R learning had significant attitudes towards mathematics. This can be seen from the high interest and motivation. Student responses to PQ4R learning and questions were also very good. This provides good information about students' attitudes towards learning mathematics in high school so that they can apply good and correct mathematics. Learning mathematics requires an analysis of students' attitudes to feel happy and motivated in learning mathematics on an ongoing basis.
\end{abstract}

\begin{tabular}{|c|c|}
\hline \multicolumn{2}{|c|}{ ARTICLE INFORMATION } \\
\hline Keywords & Article History \\
\hline Mathematical Problems & Submitted Jun 27, 2021 \\
\hline PQ4R & Revised Oct 27, 2021 \\
\hline Student Attitude Toward Mathematics & Accepted Oct 29, 2021 \\
\hline Corresponding Author & \\
\hline
\end{tabular}

Taufiqulloh Dahlan

Universitas Pendidikan Indonesia, Universitas Pasundan

Jl.Dr. Setiabudi No.229, Bandung, Indonesia, Jl. Tamansari No.6-8, Bandung, Indonesia

Email: taufiqulloh@unpas.ac.id

\section{How to Cite}

Dahlan, T., Darhim, D., Juandi, D., Gardenia, N., \& Kandaga, T. (2021). High School Students Attitudes Towards Mathematics Lessons Using the PQ4R Strategy and Problem Posing Mathematical Problems. Kalamatika: Jurnal Pendidikan Matematika, 6(2), 171-180.

https://doi.org/10.22236/KALAMATIKA.vol6no2.2021pp171-180

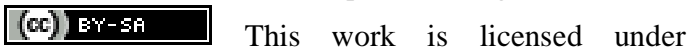
a Creative Commons Attribution - ShareAlike 4.0 International License. 


\section{INTRODUCTION}

Mathematics is one of the disciplines that time for most students is considered difficult. While on the other hand, mathematics is an influential part of daily life; however, it is considered useful in other parts because it is a good predictor for children when taking formal school compared to emotional and social skills (Siregar, 2017). Various ways for solving students' obstacles in learning have often been implemented, but the results will not achieve the expected results. One way is to analyze the triggers of mathematics learning problems is from the aspects that come from "the student's inner self" or from "the student's outer self" (Dahlan, 2016). To date, the triggers difficulties from "within the student" is mainly exposed to deep attention as if there are no triggers for difficulties that come from "outside the students," for example, "how to present lessons" or "learning atmosphere" carried out by Rahayu, Prahmana, \& Istiandaru (2021).

Teachers need to provide learning opportunities that increase students' use of the language of mathematics so that students know more about the meaning of mathematics which is the basic concept (Pourdavood \& Wachira, 2016). Based on the factor of students who do not understand a concept to the material being taught due to the assumption that knowledge can be completely transferred from the understanding of the teacher's thinking to the minds of students, the teacher focuses the mathematics learning process in how to enter related knowledge with mathematics as optimally as possible to students. Furthermore, in the aspect of current change, teachers are challenged so that their duties and roles are not only as sources of information but as learning motivators so that students can understand and build their understanding independently so that they cross various activities, such as communication (Gardenia, Herman, \& Dahlan, 2019; Kandaga, Dahlan, Gardenia, Darta, \& Saputra, 2021). Therefore, teachers are expected to have their duties and roles not only as a source of information but also as a learning motivator so that students can understand and build their understanding independently. (Septi \& Afifah, 2015) emphasized that one of the ways that can be done is through optimizing the teacher's function during the learning process. So that this section can be carried out if the teacher is good at setting learning in the classroom to be optimal, and its function as a facilitator is processed when learning takes place.

One of the efforts that can be done to optimize mathematical problem-solving skills is through problem presentation (Sukma \& Priatna, 2021). In addition, Silver \& Cai (in Sipayung, Imelda, Siswono, \& Masriyah, 2021) said that the results of the study showed that instructing students to participate when related activities through presenting 
problems/questions (often simple, for example, rewriting story questions) had a positive impact on their problem-solving skills and attitudes towards mathematics. Siswono also said that there appears to be a positive correlation between the ability to pose problems and student achievement. The National Council of Teachers of Mathematics (NCTM) recommends the implementation of problem-posing when learning mathematics because it is considered that problem-posing contributes to increasing students' knowledge and understanding in the section on improving mathematical concepts (English, 1998). NCTM recommends that students be given opportunities to investigate and formulate questions that come from problem situations.

The problem that arose is learning how to optimize students' mathematical problem-posing skills. According to Weinstein and Mayer (Widyantari, Suardana, \& Devi, 2019), optimal learning is a learning process that includes teaching, remembering, thinking, and motivating yourself. Seen from the previous opinion revealed that optimal teaching is learning that can make students independent in learning. Students' independence in learning can be started by giving independent assignments, where students are allowed to summarize, arrange questions, explain and predict. Therefore, it is not impossible for a teacher to give reading assignments to students, both the task of reading books and sheets of material descriptions as accompanying material to understand a concept being taught. Improving students' mathematical problem-posing abilities can be carried out while making changes during the learning process (Kandaga et al., 2021). In this section, it is important to develop a method that can optimize students' mathematical problem posing skills and positive attitudes towards mathematics. Methods that can increase students' positive attitudes and mathematical problem posing must be designed to form and develop knowledge itself (Jatisunda \& Nahdi, 2020).

Meanwhile, (Greenhalgh \& Rosenblatt, 2018) said that some readers do not walk simply to acquire basic reading and text knowledge when reading mathematics. However, it requires other things such as knowledge, interests (needs), and feelings to interpret, compare, get, study, organize, and finally implement the parts contained in the reading. Concerning these reading activities, especially in mathematics, Bell (in Gazali, 2016) stated that what causes students to have difficulty learning mathematics is the lack of reading skills seen from the whole and the inability to understand in particular. Especially, mathematics is the knowledge that studies full of mathematical symbols and terms.

Based on (Suprijono, 2016) revealed PQ4R method, an improved method so that 
students can read optimally with preview activities (students can create main ideas in reading), question (students can construct questions to themselves), read (students can examine all the readings in order to find answers to all the questions that have been made), reflect (students can carry out reflection through the process of interpreting what they have read), recite (students can think back on the information they have read), learned), and review (students can make conclusions to answer aspects of the questions that have been asked).

In line with this, the indicators of student learning activities related to the PQ4R learning method are based on (Trianto, 2011) and (Gardenia et al, 2019) which will be addressed when the research process includes preview activities (reviews) in which students read briefly and deftly in order to obtain the main idea / learning objectives to be addressed, question activities (ask) where students focus on information from the teacher and answer the questions he has made, read activities, in which students study actively while responding to responses about aspects that have been studied and answer the questions they construct, reflect activities, in which students solve problems based on the instructions presented by the teacher based on knowledge that has been obtained through reading materials, recite activities (contemplating) in which students analyze and answer questions and construct conclusions, and review activities (check) in which students examine conclusions they have drawn up and reread the reading material. From the previous explanation, the authors was motivated to research to get information about students' attitudes towards questions about the ability to submit mathematical problems for high school students through the PQ4R method (Noviani, 2021). Thus, PQ4R can improve students' ability to do good and correct questions, which is expected to improve mathematical problem-solving skills.

\section{METHOD}

In this research, data analysis was done using qualitative methods. Researchers investigated some information about students' attitudes and perceptions of mathematics learning given PQ4R. The population in this study was all Year 11 students in the city of Bandung. The research samples were taken from one Year 11 social classroom, and the sampling was done by purposive sampling. The sample is determined intentionally and takes other aspects into account (Sugiyono, 2015). The samples were one class based on the six available classes. 
The teaching material implemented in this research process was student worksheets adapted to the PQ4R learning strategy. Furthermore, the data was collected through a questionnaire on student attitude. The items of the questionnaire are presented in Table 1.

Table 1. Student Questionnaire

\begin{tabular}{|c|c|c|}
\hline No & Question & SA A D SD \\
\hline 1 & I like math lessons & \\
\hline 2 & Mathematics is a useful science. & \\
\hline 3 & I like solving math problems in different ways. & \\
\hline 4 & I always try to do math assignments to the best of my ability. & \\
\hline 5 & $\begin{array}{l}\text { I review the math subject matter given by the teacher at school } \\
\text { at home. }\end{array}$ & \\
\hline 6 & PQ4R learning strategies are more fun than regular math learning & \\
\hline 7 & It is easier for me to understand concepts by using the PQ4R learning strategy. & \\
\hline 8 & The PQ4R learning strategy helps me to overcome difficulties in solving math problems. & \\
\hline 9 & The PQ4R learning strategy made me dare to ask the teacher. & \\
\hline 10 & The PQ4R learning strategy fosters the courage for me to express my opinion. & \\
\hline 11 & The PQ4R learning strategy fosters a sense of pleasure in discussing. & \\
\hline 12 & Problem-posing questions encourage me to find new ideas. & \\
\hline 13 & Asking questions made me get used to thinking critically. & \\
\hline 14 & Assignment Problems improve my understanding of the material being studied. & \\
\hline 15 & Mathematics is a very difficult and confusing subject. & \\
\hline 16 & I don't feel the benefits of mathematics when studying other sciences. & \\
\hline 17 & I have difficulty with symbolic terms used in mathematics. & \\
\hline 18 & In learning mathematics, I prefer a teacher who explains the problem to me. & \\
\hline 19 & I don't like how to learn in class using the PQ4R learning strategy. & \\
\hline 20 & I feel uncomfortable during learning mathematics using the PQ4R learning strategy. & \\
\hline 21 & $\begin{array}{l}\text { The PQ4R learning strategy adds tension and the feeling of tension and discomfort in learning } \\
\text { in class. }\end{array}$ & \\
\hline 22 & I feel burdened to present assignments in the form of a Problem Posing. & \\
\hline 23 & Problem-posing problems are very boring. & \\
\hline 24 & Troubleshooting Assignments stifles my creativity. & \\
\hline 25 & I am not happy if the teacher gives the steps for posing a problem in solving the problem. & \\
\hline
\end{tabular}

Where :

$\begin{array}{ll}\text { SA } & \text { : Strongly Agree } \\ \text { A } & : \text { Agree } \\ \text { D } & : \text { Disagree } \\ \text { SD } & : \text { Strongly Disagree }\end{array}$

The questionnaire data was then presented in the percentage by the following formula.

$$
P=\frac{f}{n} \times 100 \%
$$

Where:

$\begin{array}{ll}\mathrm{P} & : \text { Percentage of Answers } \\ \mathrm{f} & : \text { Answer Frequency } \\ \mathrm{n} & : \text { Number of Answers }\end{array}$

\section{RESULT AND DISCUSSION}

Questionnaire analysis was carried out to obtain the best possible data. The questionnaire was one of the non-test instruments to obtain student responses when learning mathematics with the PQ4R learning strategy. The distribution was carried out to the experimental class after the treatment. Before the questionnaire was distributed, the 
students were reminded that whatever their answers were in the questionnaire would not affect the students' final grades.

Of all the students in the experimental class, a questionnaire was distributed to 29 students. The data that has been collected is then grouped based on the sequence of statements, the frequency of each alternative answer is calculated, and the percentage is calculated. The questionnaire distributed in the experimental class was intended to obtain data on student opinions regarding PQ4R learning. The model implemented is the Likert model. The questionnaire has 25 statement items. Table 3 displays students' attitudes about learning mathematics.

Table 3. Recapitulation of Students' Attitudes about Learning Mathematics

\begin{tabular}{|c|c|c|c|c|c|c|c|c|}
\hline \multirow{2}{*}{$\begin{array}{l}\text { No. } \\
\text { Question }\end{array}$} & \multirow{2}{*}{$\begin{array}{l}\text { Nature of } \\
\text { Statement }\end{array}$} & \multicolumn{4}{|c|}{ Response } & \multicolumn{2}{|c|}{ Attitude Score } & \multirow{2}{*}{$\begin{array}{l}\text { Alternate Score of } \\
\text { Neutral Response }\end{array}$} \\
\hline & & SA & A & $\mathrm{D}$ & SD & Items & Class & \\
\hline \multirow[t]{2}{*}{1} & Positive & 3 & 21 & 5 & 0 & 29 & 889 & 783 \\
\hline & Score & 15 & 84 & 10 & 0 & 109 & & \\
\hline \multirow[t]{2}{*}{2} & Positive & 9 & 20 & 0 & 0 & 29 & & \\
\hline & Score & 45 & 80 & 0 & 0 & 125 & & \\
\hline \multirow[t]{2}{*}{3} & Positive & 9 & 17 & 3 & 0 & 29 & & \\
\hline & Score & 45 & 86 & 6 & 0 & 119 & & \\
\hline \multirow[t]{2}{*}{4} & Positive & 8 & 19 & 2 & 0 & 29 & & \\
\hline & Score & 40 & 76 & 4 & 0 & 120 & & \\
\hline \multirow[t]{2}{*}{5} & Positive & 1 & 8 & 20 & 0 & 29 & & \\
\hline & Score & 5 & 32 & 40 & 0 & 77 & & \\
\hline \multirow[t]{2}{*}{15} & Negative & 1 & 2 & 10 & 16 & 29 & & \\
\hline & Score & 5 & 8 & 20 & 16 & 49 & & \\
\hline \multirow[t]{2}{*}{16} & Negative & 1 & 2 & 11 & 15 & 29 & & \\
\hline & Score & 5 & 8 & 22 & 15 & 50 & & \\
\hline \multirow[t]{2}{*}{17} & Negative & 11 & 15 & 3 & 0 & 29 & & \\
\hline & Score & 55 & 60 & 6 & 0 & 121 & & \\
\hline \multirow[t]{2}{*}{18} & Negative & 8 & 16 & 5 & 0 & 29 & & \\
\hline & Score & 40 & 64 & 15 & 0 & 119 & & \\
\hline
\end{tabular}

Table 4 presents data on student attitudes regarding learning mathematics using the PQ4R Learning Strategy:

Table 4. Student Attitude Statement Scores concerning PQ4R Learning

\begin{tabular}{|c|c|c|c|c|c|c|c|c|}
\hline \multirow{2}{*}{$\begin{array}{l}\text { No. } \\
\text { Statement }\end{array}$} & \multirow{2}{*}{$\begin{array}{l}\text { Nature of } \\
\text { Statement }\end{array}$} & \multicolumn{4}{|c|}{ Response } & \multicolumn{2}{|c|}{ Attitude Score } & \multirow{2}{*}{$\begin{array}{c}\text { Alternate Score } \\
\text { of Neutral } \\
\text { Response }\end{array}$} \\
\hline & & SA & A & $\mathrm{D}$ & SD & Items & Class & \\
\hline \multirow[t]{2}{*}{6} & Positive & 13 & 15 & 1 & 0 & 29 & 943 & 789 \\
\hline & Score & 65 & 60 & 2 & 0 & 127 & & \\
\hline \multirow[t]{2}{*}{7} & Positive & 10 & 18 & 1 & 0 & 29 & & \\
\hline & Score & 50 & 72 & 2 & 0 & 124 & & \\
\hline \multirow[t]{2}{*}{8} & Positive & 12 & 15 & 2 & 0 & 29 & & \\
\hline & Score & 60 & 60 & 4 & 0 & 124 & & \\
\hline \multirow[t]{2}{*}{9} & Positive & 21 & 7 & 1 & 0 & 29 & & \\
\hline & Score & 105 & 28 & 2 & 0 & 135 & & \\
\hline \multirow[t]{2}{*}{10} & Positive & 9 & 17 & 3 & 0 & 29 & & \\
\hline & Score & 45 & 68 & 6 & 0 & 119 & & \\
\hline \multirow[t]{2}{*}{11} & Positive & 13 & 16 & 0 & 0 & 29 & & \\
\hline & Score & 65 & 64 & 0 & 0 & 129 & & \\
\hline \multirow[t]{2}{*}{19} & Negative & 0 & 2 & 27 & 0 & 29 & & \\
\hline & Score & 0 & 4 & 54 & 0 & 58 & & \\
\hline \multirow[t]{2}{*}{20} & Negative & 0 & 7 & 21 & 1 & 29 & & \\
\hline & Score & 0 & 28 & 42 & 1 & 71 & & \\
\hline \multirow[t]{2}{*}{21} & Negative & 0 & 0 & 27 & 2 & 29 & & \\
\hline & Score & 0 & 0 & 54 & 2 & 56 & & \\
\hline
\end{tabular}


Table 5 displays the result data from students' attitudes regarding problem posing mathematical problems.

Table 5. Data on Student Attitude Statements Regarding Problem Posing Mathematical Problems Mathematical Problems

\begin{tabular}{|c|c|c|c|c|c|c|c|c|}
\hline \multirow{2}{*}{$\begin{array}{l}\text { No. } \\
\text { Statement }\end{array}$} & \multirow{2}{*}{$\begin{array}{l}\text { Nature of } \\
\text { Statement }\end{array}$} & \multicolumn{4}{|c|}{ Response } & \multicolumn{2}{|c|}{ Attitude Score } & \multirow{2}{*}{$\begin{array}{l}\text { Alternate Score of } \\
\text { Neutral Response }\end{array}$} \\
\hline & & SA & A & $\mathrm{D}$ & SD & Items & Class & \\
\hline \multirow[t]{2}{*}{12} & Positive & 17 & 13 & 2 & 0 & 29 & 626 & 609 \\
\hline & Score & 85 & 52 & 4 & 0 & 141 & & \\
\hline \multirow[t]{2}{*}{13} & Positive & 12 & 14 & 3 & 0 & 29 & & \\
\hline & Score & 60 & 56 & 6 & 0 & 115 & & \\
\hline \multirow[t]{2}{*}{14} & Negative & 9 & 15 & 5 & 0 & 29 & & \\
\hline & Score & 45 & 60 & 10 & 0 & 56 & & \\
\hline \multirow[t]{2}{*}{22} & Negative & 0 & 1 & 26 & 2 & 29 & & \\
\hline & Score & 0 & 4 & 52 & 2 & 56 & & \\
\hline \multirow[t]{2}{*}{23} & Negative & 0 & 7 & 22 & 0 & 29 & & \\
\hline & Score & 0 & 28 & 44 & 0 & 72 & & \\
\hline \multirow[t]{2}{*}{24} & Negative & 0 & 3 & 26 & 0 & 29 & & \\
\hline & Score & 0 & 14 & 52 & 0 & 66 & & \\
\hline \multirow[t]{2}{*}{25} & Negative & 0 & 2 & 19 & 8 & 29 & & \\
\hline & Score & 0 & 8 & 38 & 8 & 54 & & \\
\hline
\end{tabular}

Discussion of the results of the questionnaire data analysis that has been carried out in the study. To get the response of students' attitudes about learning mathematics using the PQ4R learning strategy, a non-test instrument was used in a questionnaire. Furthermore, the results of the questionnaire data analysis that has been carried out are regarding student responses to learning mathematics. Based on the results of the questionnaire data processing, it is known that the total score of the attitude of the experimental class is 886 while the alternative score of the neutral answer is 696. It is clear that $886>696$. In other words, the total score of the attitude of the experimental class is better than the alternative score of the neutral answer. That is, the experimental class gave a positive response about learning mathematics.

Furthermore, regarding students' attitudes about learning mathematics using the PQ4R learning strategy, the results of the questionnaire data analysis, it is known that the total score of the attitude of the experimental class is 943 while the alternative score of the neutral response is 783. It is clear that $943>783$. In other words, the total score of the attitude of the experimental class is better than the alternative score of the neutral answer. That is, the experimental class emphasizes good attitudes about learning mathematics using the PQ4R learning strategy.

Concerning the student's response to the problem posing mathematical problems, the results of the questionnaire data processing show that the total score of the attitude of the experimental class is 626 while the alternative score of the neutral answer is 609. It is clear that $626>609$. In other words, the total score of the attitude of the experimental class 
is greater than the alternative score of the neutral answer. That is, the experimental class gives a positive attitude towards the problem posing mathematical problems.

\section{CONCLUSION}

Students' attitude regarding the PQ4R learning process, along with the problem posing mathematical problems, shows good interest and motivation. Based on this, it was monitored based on student responses from the attitude scale obtained from the data results, namely the general aspects of student responses using PQ4R learning and very good questions. So it can be concluded that the students' activities using PQ4R learning and the overall mathematical problem posing problems are positive. This provides good information about students' attitudes towards learning mathematics in high school, so that they can apply good and correct mathematics. Learning mathematics requires an analysis of student attitudes to feel happy and motivated in learning mathematics on an ongoing basis.

\section{ACKNOWLEDGMENTS}

Researchers would like to thank Universitas Pasundan, Universitas Pendidikan Indonesia, Kemenristekdikti, BPPDN and the research subjects who have provided the opportunities, facilities, and infrastructure for researchers to carry out this research.

\section{REFERENCES}

Dahlan, T. (2016). Pengaruh Model Pembelajaran Kooperatif Tipe Tam Assisted Idividualization dan Jigsaw Terhadap Kemampuan Pemecahan Masalah Matematik Siswa MTS Pada Pokok Bahsan Relasi dan Fungsi. Symmetry: Pasundan Journal of Research in Mathematics Learning and Education, I(1), 29-38. Retrieved from https://journal.unpas.ac.id/index.php/symmetry/article/view/217/90

English, L. D. (1998). Children's Problem Posing within Formal and Informal Contexts. Journal for Research in Mathematics Education, 29(1), 83-106. Retrieved from https://pubs.nctm.org/view/journals/jrme/29/1/article-p83.xml

Gardenia, N., Herman, T., \& Dahlan, T. (2019). PQ4R Strategy (Preview, Question, Read, Reflection, Recite, Review) for Mathematical Communication Ability. Proceedings of the 3rd Asian Education Symposium (AES 2018), 253(Aes 2018), 322-327. https://doi.org/10.2991/aes-18.2019.75

Greenhalgh, L. Z., \& Rosenblatt. (2018). Job insecurity: Towards Conceptual Clarity. 
Gazali, R. Y. (2016). Pembelajaran Matematika Yang Bermakna. Math Didactic, 2(3), 181-190. https://doi.org/10.33654/math.v2i3.47

Jatisunda, M. G., \& Nahdi, D. S. (2020). Kemampuan Pemecahan Masalah Matematis melalui Pembelajaran Berbasis Masalah dengan Scaffolding. Jurnal Elemen, 6(2), 228-243. https://doi.org/10.29408/jel.v6i2.2042

Kandaga, T., Dahlan, T., Gardenia, N., Darta, \& Saputra, J. (2021). A lesson study to foster prospective teachers' disposition in STEM education. Journal of Physics: Conference Series, 1806(1), 1-7. https://doi.org/10.1088/1742-6596/1806/1/012107

Noviani, J. (2021). Perceptions of Mathematics Education Students Toward E-Learning During the Covid-19 Pandemic. Kalamatika: Jurnal Pendidikan Matematika, 6(1), 15-30. https://doi.org/10.22236/kalamatika.vol6no1.2021pp15-30

Pourdavood, B. R. G., \& Wachira, P. (2016). Importance of Mathematical Communication and Discourse in Secondary Classrooms. Global Journal of Science Frontier Research: Mathematics and Decision Sciences, 15(10), 1-13. Retrieved from https://globaljournals.org/GJSFR_Volume15/2-Importance-of-Mathematical.pdf

Rahayu, W., Prahmana, R. C. I., \& Istiandaru, A. (2021). The Innovative Learning of Social Arithmetic using Realistic Mathematics Education Approach. Jurnal Elemen, 7(1), 29-57. https://doi.org/10.29408/jel.v7i1.2676

Septi, D., \& Afifah, N. (2015). Berdasarkan Gaya Kognitif. Jurnal Pendidikan Dan Pembelajaran Matematika (JP2M), 1(2), 100-111. Retrieved from https://jurnal.stkippgritulungagung.ac.id/index.php/jp2m/article/view/198/81

Sipayung, T. N., Imelda, Siswono, T. Y. E., \& Masriyah. (2021). The preliminary study of students' creative problem-solving ability. Journal of Physics: Conference Series, 1836(1), 1-14. https://doi.org/10.1088/1742-6596/1836/1/012052

Siregar, N. R. (2017). Persepsi Siswa Pada Pelajaran Matematika: Studi Pendahuluan Pada Siswa yang Menyenangi Game. Prosiding Temu Ilmiah X Ikatan Psikologi Perkembangan Indonesia, 1, 224-232. Retrieved from jurnal.unissula.ac.id/index.php/ippi/article/view/2193

Sugiyono. (2015). Penelitian \& Pengembangan (Research and Development/R\&D). Bandung: Alfabeta. 
Sukma, Y., \& Priatna, N. (2021). Mathematics Teachers' Response To Online Learning During the Covid-19 Pandemic: Challenges and Opportunities. Kalamatika: Jurnal Pendidikan Matematika, 6(1), 1-14. https://doi.org/10.22236/kalamatika.vol6no1.2021pp1-14

Suprijono, A. (2016). Model-model pembelajaran emansipatoris. Yogyakarta: Pustaka Pelajar.

Trianto. (2011). Model Pembelajaran Terpadu Konsep Strategi Dan Implementasinya Dalam Kurikulum Tingkat Satuan Pendidikan. Jakarta: Bumi Aksara.

Widyantari, N. K. S., Suardana, I. N., \& Devi, N. L. P. L. (2019). Pengaruh Strategi Belajar Kognitif, Metakognitif Dan Sosial Afektif Terhadap Hasil Belajar Ipa. Jurnal Pendidikan Dan Pembelajaran Sains Indonesia (JPPSI), 2(2), 151. https://doi.org/10.23887/jppsi.v2i2.19384 